$\mathbb{T}$ periodica polytechnica

Chemical Engineering

$51 / 1(2007) 33+37$

doi: $10.3311 /$ pp.ch.2007-1.06

web: http://www.pp.bme.hu/ch

(c) Periodica Polytechnica 2007

RESEARCH ARTICLE

\section{Enhancing activated sludge nitrification through seeding from a downstream nitrifying fixed-film reactor}

\author{
Gábor Tardy / Andrea Jobbágy
}

Received 2005-09-14

\begin{abstract}
An ASM1-based mathematical model was developed for the description of the combined activated sludge-biofilter system of the Southpest Wastewater Treatment Plant, Budapest, Hungary. This model includes the interactions of the activated sludge and biofilter units, i.e. the influence of both the clarified activated sludge effluent and the backwashed nitrifying and denitrifying microorganisms. Concentration profile measurements have been carried out throughout the combined system in order to track the biological processes. Optimization possibilities of the existing combined plant were investigated by mathematical simulations under the different detected operational conditions. In these studies concentration data measured on separate days and the appropriate flow rates of the preclarified influent and the recycled streams registered at the treatment plant were used. Simulation results showed that $N$-removal of the activated sludge unit could be highly intensified by appropriate aeration, that would facilitate the efficient growth of backwashed biomass. However, in some cases, shortage of readily biodegradable carbon source proved to be the limit of the benefits available.
\end{abstract}

\section{Keywords}

activated sludge $\cdot$ biofilter $\cdot$ denitrification $\cdot$ mathematical modelling $\cdot$ nitrification $\cdot$ backseeding

\section{Acknowledgement}

Developement of the simulation model was supported by the Hungarian Scientific Research Fund within the frames of OTKA T037893 project. The full-scale research was funded by the Budapest Municipal Sewerage Company Ltd.

\section{Gábor Tardy}

Department of Agricultural Chemical Technology, Budapest University of Technology and Economics, H-1111, Budapest, Szt. Gellért tér 4., Hungary e-mail: gtardy@mail.bme.hu

\section{Andrea Jobbágy}

Department of Agricultural Chemical Technology, BME e-mail: ajobbagy@mail.bme.hu

\section{Introduction}

Southpest Wastewater Treatment Plant (Southpest WWTP), the first wastewater treatment plant of Budapest, Hungary, was established in 1966. The treatment technology contained a highload, fully aerated activated sludge unit with a capacity of 30 $000 \mathrm{~m}^{3} / \mathrm{d}$ (with a solids residence time, SRT of 2-3 days) following preliminary treatment and primary clarification. In the early 1980s the plant was enlarged by the addition of two more, similarly arranged treatment trains. Modifications in the activated sludge bioreactor configuration led to considerable improvement regarding both elimination of carbon source and sludge settling properties [4]. However, biological nutrient removal proved to be unstable and not efficient for meeting the effluent requirements of the sensitive receiving body. Nitrification occurred just randomly, first of all at high temperatures. Due to unexpected nitrification, considerable amounts of nitrate were detected in the return sludge, leading to the deterioration of biological phosphorus removal.

In order to increase the capacity of Southpest WWTP to 120 $000 \mathrm{~m}^{3} \mathrm{~d}^{-1}$ as well as to improve its performance, a bidding procedure was carried out in 1998. Regarding the restricted area available for construction, as well as the low total $\mathrm{N}$ effluent requirement $\left(10 \mathrm{mgN}^{-1}\right)$, implementation of a two-stage biofilter system was decided. The original design idea included a fully aerated, high-load activated sludge unit followed by nitrification $(\mathrm{N})$ and denitrification $(\mathrm{DN})$ filters [5].

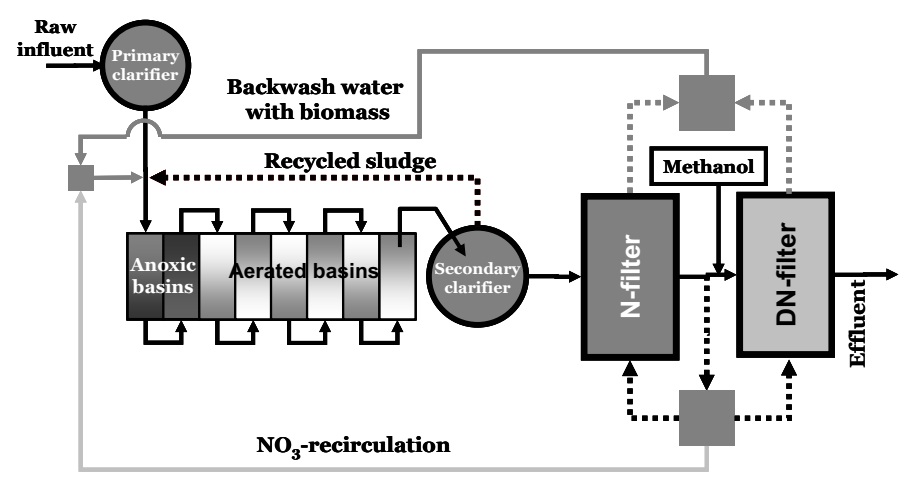

Fig. 1. Scheme of the Southpest Wastewater Treatment Plant

During the discussions with the competitors, however, a mod- 
ification was developed for possibly using the carbon source of the wastewater for denitrification through recirculating the nitrate-rich effluent of the $\mathrm{N}$-filters to the head of the 8 stage activated sludge unit (see Fig. 1). Therefore, in the first four basins of the activated sludge system also mixers were installed to be able to maintain anoxic conditions. In the current operation, the $1^{\text {st }}$ and the $2^{\text {nd }}$ basins are anoxic and the $3^{r d}$ and $4^{\text {th }}$ ones are aerated. Regarding the short capacity of the existing secondary clarifiers, recirculation of the nitrified wastewater was assumed to be feasible only until the plant reaches the nominal influent flow-rate. Both filters are backwashed by the effluent of the Nfilter, and the excess biomass is wasted through the activated sludge unit. It was assumed that this technological solution may provide seeding for the activated sludge unit [2] and may, therefore, enhance and stabilize the randomly occurring nitrification observed earlier [4]. However, in order to verify or abandon this hypothesis and analyse the different treatment options, a mathematical model had to be developed for the simulation of the interactions in the combined activated sludge-biofilter system.

\section{Simulation Model}

\section{Description of the Model}

In the simulation studies the Activated Sludge Model (ASM) No.1 [3] was used as a basis. This had to be supplemented with the description of the quality of the unified recirculated streams deriving from the backwash water of the $\mathrm{N}$ - and DN-filters as well as from the nitrate-rich effluent of the $\mathrm{N}$-filter. In the course of describing the processes occurring in the biofilters, the following assumptions were made [5]:

- Concentration of $\mathrm{NO}_{3}-\mathrm{N}$ in the $\mathrm{N}$-filter effluent was calculated regarding the difference of influent and effluent $\mathrm{NH}_{4}-\mathrm{N}$ concentrations, supplemented by the concentration of eventually occurring $\mathrm{NO}_{3}-\mathrm{N}$ coming from the activated sludge unit. Incorporation of nitrogen into biomass was assumed to be negligible.

- It was assumed that practically all of the suspended solids leaving the secondary clarifier of the activated sludge unit are retained in the $\mathrm{N}$-filter, which was in accordance with the observations. Estimation of the total effluent suspended solids concentration of the secondary clarifiers was based on measured data, whereas the ratio of the different fractions was adjusted to the results of the ASM1 model applied.

- It was hypothesized that all of the suspended solids having left the secondary clarifiers or having been produced in the filters are fully backwashed and, therefore, end up in the influent of the activated sludge unit.

Production of autotrophic bacteria $\left(P_{a u t}\right)$ in the N-filters was calculated by using Eq. (1). In this equation $Y_{N H_{4}-N}$ [g biomass $\left.\mathrm{COD} \mathrm{g}{ }^{-1} \mathrm{NH}_{4}-\mathrm{N}\right]$ represents the growth yield, $\Delta \mathrm{NH}_{4} N\left[\mathrm{~g} \mathrm{~m}^{3}\right]$ stands for the difference between the influent and effluent ammonia concentration of the N-filters, whereas $Q_{N}\left[\mathrm{~m}^{3} \mathrm{~d}^{-1}\right]$ in- dicates the total flow rate through the $\mathrm{N}$-filters. The value of $Y_{N_{4}-N}$ was set to $0.32 \mathrm{~g}$ biomass COD g ${ }^{-1} \mathrm{NH}_{4}-\mathrm{N}$ [5].

$$
P_{\text {aut }}=Y_{N H 4-N} \cdot \Delta N H_{4}-N \cdot Q_{N}\left[\mathrm{~g}_{\text {biomass COD d }}{ }^{-1}\right]
$$

In the DN-filters of the Southpest WWTP methanol is used as external carbon source. The production of the relevant heterotrophic bacteria can be described by Eq. (2).

$$
\begin{aligned}
P_{h e t}= & Y_{X / M e O H} \cdot R_{M e O H / N O 3-N} \cdot \Delta N O_{3} \\
& -N \cdot Q_{D N}\left[\mathrm{~g} \text { biomass COD d }{ }^{-1}\right]
\end{aligned}
$$

where $Y_{X / \mathrm{MeOH}}$ is the heterotrophic yield on methanol as carbon source and was set to $0.4 \mathrm{~g}$ biomass COD $\mathrm{g}^{-1} \mathrm{COD}$ $\mathrm{MeOH}$ on the basis of the data available in the literature (see [5]). $\mathrm{R}_{\mathrm{MeOH} / \mathrm{NO}_{3}-\mathrm{N}}$ is the rate of methanol consumed for nitrate elimination. Considering that in the post denitrification filter nitrate serves both as nitrogen source and as electron accep-

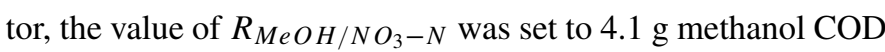
$\mathrm{g}^{-1} \mathrm{NO}_{3}-\mathrm{N}$. Since the recirculated effluent of the $\mathrm{N}$-filter as well as the backwashed biomass of the different biofilm reactors may considerably change the quality of the influent of the activated sludge system, and the activated sludge effluent quality influences the quality of the recycled streams, the calculations necessarily involved an iteration routine. The eventual inactivity of the recirculated biomass, caused by the different conditions in the activated sludge basins and the biofilters, were modelled through the 'viability factor' $\left(f_{v}\right)$, representing the ratio of the recirculated biomass being active in the activated sludge system.

\section{Simulation of Different Design Options}

Simulation studies were carried out in order to investigate the effects of backseeding on the performance of the combined activated sludge-biofilm system, simulation studies were carried out [5]. Mean values of representative plant data were used as operational parameters. Values of the kinetic and stoichiometric parameters were taken from the literature [3] .

Data obtained for three different design options at different temperatures are shown in Fig.2. Both effluent $\mathrm{NH}_{4}-\mathrm{N}$ and TIN (Total Inorganic Nitrogen) concentrations of the activated sludge unit are the highest without applying the N-recirculation (option 'No N-rec.'). In this case, nitrification in the aerated basins and consequent denitrification in the anoxic basins can only be observed at higher temperatures. Applying the N-recirculation without efficient backseeding (option 'No seed in rec.') results in decreased $\mathrm{NH}_{4}-\mathrm{N}$ concentrations, caused by the dilution with the recirculated nitrified water. At the same time the activated sludge effluent TIN concentration dropped through the denitrification of the nitrate content of the N-recirculation in the anoxic basins. Data obtained for the option of effective backseeding ('Seed in rec.') support, that seeding may enhance nitrification in the activated sludge basins and therefore reduce the effluent TIN concentration and consequently the methanol demand in the $\mathrm{DN}$-filters through the denitrification of the nitrate, delivered by 
Fig. 2. Calculated activated sludge effluent $\mathrm{NH}_{4}$ $\mathrm{N}, \mathrm{NO}_{3}-\mathrm{N}$ and TIN concentration values at MLSS $=$ $3 \mathrm{~g}^{-1}$
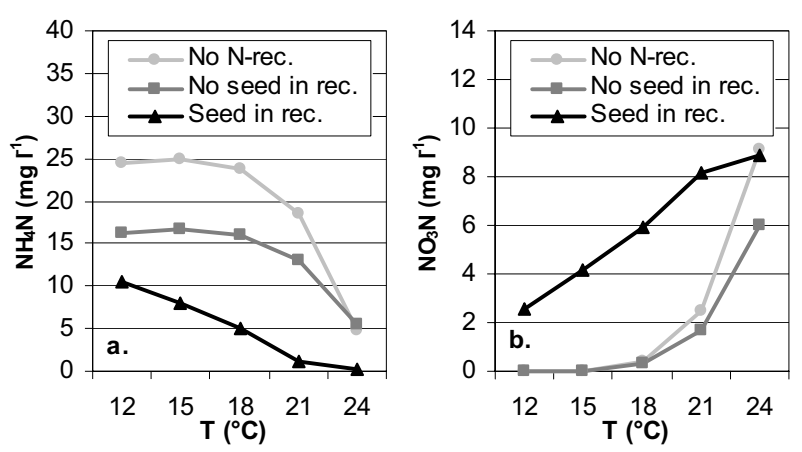

the recycled sludge to the anoxic basins. After all, it is obvious that considerable amounts of methanol and related aeration energy costs can be saved by choosing the optimum operational settings.

Evaluation of the plant startup data supported that under certain conditions, efficient nitrification may occur in the activated sludge unit (see Fig. 3 from 10.8 to 10.14). Simulation with the corresponding data proved that this nitrification efficiency can only be achieved in case of backseeding of the nitrifying biomass from the $\mathrm{N}$-filter and appropriate aeration of the activated sludge basins [5].

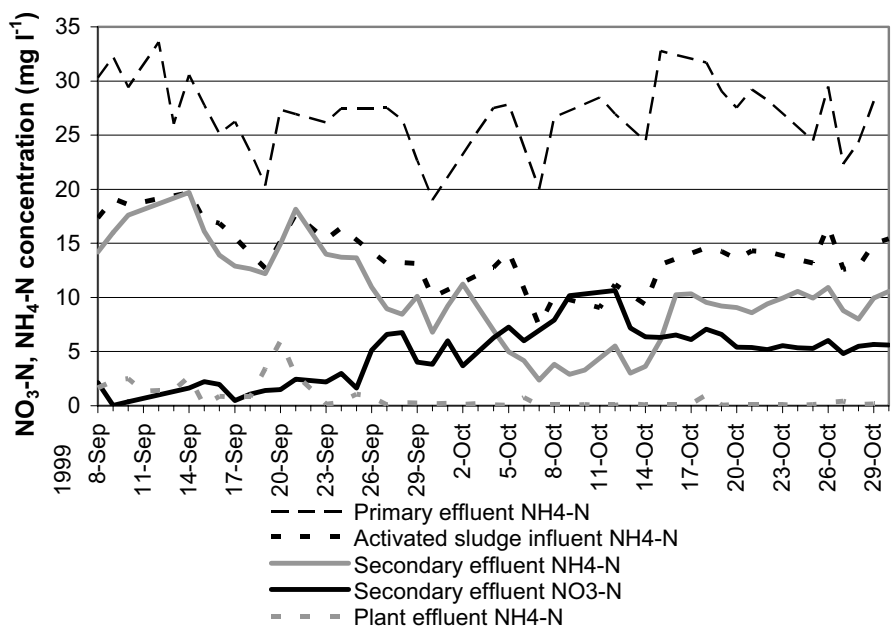

Fig. 3. $\mathrm{NH}_{4}-\mathrm{N}$ and $\mathrm{NO}_{3}-\mathrm{N}$ concentration data of the startup and trial operation

\section{Evaluation of the Full Scale Results}

In order to track the biological processes at the Southpest WWTP, concentration profile measurements of COD, TOC, $\mathrm{NH}_{4}-\mathrm{N}, \mathrm{NO}_{3}-\mathrm{N}, \mathrm{NO}_{2}-\mathrm{N}, \mathrm{PO}_{4}^{3-}$ and dissolved oxygen were carried out nine different times in 2004. In addition, concentrations of the influent and effluent BOD, TKN, TSS as well as values of $\mathrm{pH}$ and temperature were also measured. Optimization possibilities of the existing combined plant were investigated by mathematical simulations under the different detected operational conditions. Actual flow rates, measured MLSS and DO concentration values together whith the influent ASM parameters calculated from the measured concentration values are presented in Table 1 .

Assuming that in the aerated reactors the same DO (dissolved oxygen) concentration values can be maintained with or without nitrification, altough the aeration demand is highly different in the two cases, the following possibilities were tested during the simulation studies:

- Option 'Inefficient seeding, measured DO': the calculations were made with the measured DO values and with the assumption that most of the recirculated nitrifiers are unable to grow and become inactive through lysis in the activated sludge basins, due to the inappropriate aeration at the measured DO concentration values $\left(f_{v}=0.1\right)$.

- Option 'Efficient seeding, measured DO': most of the recirculated nitrifiers were presumed to remain active in the activated sludge basins due to appropriate air supply at the measured DO concentration values $\left(f_{v}=0.9\right)$.

- Option 'Efficient seeding, appropriate DO': the viability factor was maintained at $f_{v}=0.9$, and the DO values were set to $0 \mathrm{mg} \mathrm{l}^{-1}$ in the anoxic basins and at least to $2 \mathrm{mg} \mathrm{l}^{-1}$ in the aerated basins in order to simulate favourable conditions for both nitrification and denitrification.

Measured and calculated activated sludge effluent $\mathrm{NH}_{4}-\mathrm{N}$ concentration values are presented in Fig. 4 . It can be concluded that the option 'Inefficient seeding, measured DO' fits best the measured data, which may refer to the fact, that due to the inappropriate conditions, the nitrifying biomass could not efficiently grow in the activated sludge unit. Simulation with efficient seeding at the measured DO values shows that in case of enough air supply, nitrification takes place in the activated sludge basins resulting in highly decreased effluent $\mathrm{NH}_{4}-\mathrm{N}$ and increased $\mathrm{NO}_{3}-\mathrm{N}$ concentrations (see Figs. 4 and 4.b) values. At the same time, in most of the cases the TIN concentration (see Fig. 4.), and consequently the methanol and aeration costs also decrease because of the denitrification of the nitrate recirculated into the anoxic activated sludge basins. Through applying appropriate DO levels ('Efficient seeding, appropriate DO') even more efficient denitrification and nitrification may be achieved in the activated sludge system, resulting in lower effluent TIN values. It is important to note, that in some of the cases, the nitrate concentration of the activated sludge effluent could have been decreased by increased recirculation of the nitrified nitrate in the aerated basins.

As Fig. $4 \mathrm{c}$ shows, the benefits of backseeding and appropriate aeration in the N-removal proved to be different in the different 
Tab. 1. Simulation parameters for the activated sludge unit

\begin{tabular}{|c|c|c|c|c|c|c|c|c|c|}
\hline DATE & 22.07 .04 & 04.08 .04 & 17.08 .04 & 07.09 .04 & 27.09 .04 & 07.10 .04 & 28.10 .04 & 18.11 .04 & 02.12 .04 \\
\hline \multicolumn{10}{|l|}{ Flow rates $\left(m^{3} / d\right)$} \\
\hline Primary clarifier effl. & 9840 & 10740 & 9835 & 11305 & 10395 & 10115 & 10270 & 10426 & 12170 \\
\hline N-recirculation & 4584 & 4537 & 4538 & 4551 & 4537 & 4244.5 & 4583 & 4536 & 4591 \\
\hline Total influent & 14424 & 15277 & 14373 & 15856 & 14932 & 14360 & 14853 & 14962 & 16761 \\
\hline Sludge recirculation & 12023 & 12008 & 12029 & 12033 & 12007 & 11981 & 12010 & 12016 & 12037 \\
\hline MLSS (g/l) & 2.47 & 2.42 & 2.28 & 2.83 & 2.67 & 3.4 & 2.54 & 2.47 & 2.62 \\
\hline \multicolumn{10}{|c|}{ Dissolv. Oxygen (mg/l) } \\
\hline 1. reactor (anoxic) & 0.04 & 0.03 & 0.04 & 0.07 & 0.06 & 0.06 & 0.07 & 0.03 & 0.12 \\
\hline 2. reactor (anoxic) & 0.02 & 0.03 & 0.04 & 0.06 & 0.09 & 0.06 & 0.07 & 0.04 & 0.09 \\
\hline 3. reactor & 0.11 & 0.22 & 0.32 & 0.12 & 0.12 & 0.06 & 0.10 & 0.10 & 1.14 \\
\hline 4. reactor & 0.23 & 0.23 & 0.19 & 0.12 & 0.18 & 0.10 & 0.26 & 0.24 & 2.27 \\
\hline 5. reactor & 0.43 & 0.82 & 1.13 & 0.23 & 0.37 & 0.23 & 0.40 & 0.80 & 3.53 \\
\hline 6. reactor & 2.22 & 1.90 & 2.74 & 1.55 & 1.72 & 1.08 & 0.78 & 1.89 & 3.42 \\
\hline 7. reactor & 3.01 & 3.53 & 3.73 & 3.10 & 2.46 & 1.89 & 1.41 & 3.19 & 4.37 \\
\hline 8. reactor & 5.01 & 4.98 & 5.05 & 4.43 & 3.65 & 2.97 & 2.43 & 5.53 & 6.32 \\
\hline Temperature $\left({ }^{\circ} \mathrm{C}\right)$ & 22.6 & 22.7 & 22.4 & 22.7 & 21 & 20.9 & 20.2 & 17.9 & 15.6 \\
\hline \multicolumn{10}{|l|}{ Influent Parameters } \\
\hline $\mathrm{X}_{B, H}\left(\mathrm{~g} \mathrm{COD} / \mathrm{m}^{3}\right)$ & 0 & 0 & 0 & 0 & 0 & 0 & 0 & 0 & 0 \\
\hline $\mathrm{X}_{B, A}\left(\mathrm{~g} \mathrm{COD} / \mathrm{m}^{3}\right)$ & 0 & 0 & 0 & 0 & 0 & 0 & 0 & 0 & 0 \\
\hline $\mathrm{X}_{I}\left(\mathrm{~g} \mathrm{COD} / \mathrm{m}^{3}\right)$ & 43 & 40 & 15 & 96 & 22 & 12 & 21 & 20 & 25 \\
\hline $\mathrm{X}_{S}\left(\mathrm{~g} \mathrm{COD} / \mathrm{m}^{3}\right)$ & 213 & 30 & 128 & 166 & 53 & 112 & 70 & 132 & 48 \\
\hline $\mathrm{S}_{S}\left(\mathrm{~g} \mathrm{COD} / \mathrm{m}^{3}\right)$ & 165 & 241 & 143 & 157 & 189 & 142 & 188 & 139 & 152 \\
\hline $\mathrm{S}_{N H}\left(\mathrm{~g} \mathrm{~N} / \mathrm{m}^{3}\right)$ & 48 & 56.8 & 63.2 & 48.4 & 48 & 51.2 & 31.1 & 56.3 & 37.8 \\
\hline $\mathrm{S}_{N O}\left(\mathrm{~g} \mathrm{~N} / \mathrm{m}^{3}\right)$ & 0 & 0 & 0 & 0 & 0 & 0 & 0 & 0 & 0 \\
\hline $\mathrm{S}_{N D}\left(\mathrm{~g} \mathrm{~N} / \mathrm{m}^{3}\right)$ & 3.97 & 4.74 & 2.39 & 1.77 & 8.53 & 2.83 & 3.45 & 2.92 & 2.49 \\
\hline $\mathrm{X}_{N D}\left(\mathrm{~g} \mathrm{~N} / \mathrm{m}^{3}\right)$ & 15.47 & 5.89 & 5.86 & 6.17 & 11.64 & 6.02 & 5.45 & 7.45 & 4.12 \\
\hline
\end{tabular}

investigated cases. The cause of this difference is basically the different availability of the readily biodegradable substrate $\left(S_{S}\right)$ for denitrification. For example on $04.08,15.7 \mathrm{mg} \mathrm{l}^{-1}$ excess nitrogen could be removed in case of efficient backseeding and appropriate aeration, at a relatively high (4.24) influent $\mathrm{S}_{5} / \mathrm{NH}_{4}-\mathrm{N}$ ratio. On the contrary, on 17.08 , only $3.5 \mathrm{mg} \mathrm{l}^{-1}$ excess nitrogen could be removed because of the low (2.26) influent $\mathrm{S}_{S} / \mathrm{NH}_{4}-\mathrm{N}$ ratio. Amount of excess nitrogen removed was calculated as the difference between the activated sludge effluent TIN values of the options 'Inefficient seeding, measured DO' and 'Efficient seeding, appropriate DO'. This value, divided by the TIN values of the option 'Inefficient seeding, measured DO' gives the relative improvement of N-removal efficiency in the activated sludge system, that has been presented in Fig. 5, as a function of the influent $\mathrm{S}_{S} / \mathrm{NH}_{4}-\mathrm{N}$ ratio. Obviously, at lower (2-3) $\mathrm{S}_{S} / \mathrm{NH}_{4}$ $\mathrm{N}$ ratios, the benefit is relatively low, because of the deficiency of carbon source for denitrification. On the contrary, at higher $\mathrm{S}_{S} / \mathrm{NH}_{4}-\mathrm{N}$ ratios more than $35 \%$ relative improvement of the $\mathrm{N}$ removal efficiency could be achieved in spite of the unchanged recirculation rate.

Current and earlier [5] simulation data refer to the fact that the efficient backseeding is basically hindered by the inappropriate aeration of the activated sludge unit. In order to illustrate the aeration deficiency of the activated sludge unit, the volumetric oxygen demands were calculated (with $1^{\text {st }}$ and $2^{\text {nd }}$ basins not aerated) at the same DO level with and without efficient backseeding (see Fig. 6). At the measured low DO concentrations nitrification may basically start only in the $6^{\text {th }}$ basin and therefore the volumetric oxygen demand jumps up just in the last 3 basins from $1100-1300 \mathrm{gO}_{2} \mathrm{~m}^{-3} \mathrm{~d}^{-1}$ to $2200-2500 \mathrm{gO}_{2} \mathrm{~m}^{-3}$ $\mathrm{d}^{-1}$. At appropriate $\mathrm{DO}$ values $\left(0 \mathrm{mg} \mathrm{l}^{-1}\right.$ in the anoxic basins $2 \mathrm{mg} \mathrm{l}^{-1}$ in the aerobic basins) the volumetric oxygen demand profile looks highly different from that of the measured DO, because the relatively high DO values enable efficient nitrification, and elimination of most of the ammonia already in the $3^{r d}-5^{\text {th }}$ basins.

\section{Conclusions}

Simulation studies with the ASM1-based mathematical model developed for the description of combined activated sludge-biofilm systems showed, that backseeding with the nitrifying biomass of the $\mathrm{N}$-filters may enhance nitrification in the activated sludge unit. This may lead to considerable improvement in the treatment efficiency and to savings in the operation costs. Full-scale data of the startup period of the Southpest Wastewater Treatment Plant verified that under certain conditions, efficient nitrification does occur in the high load activated sludge unit. 

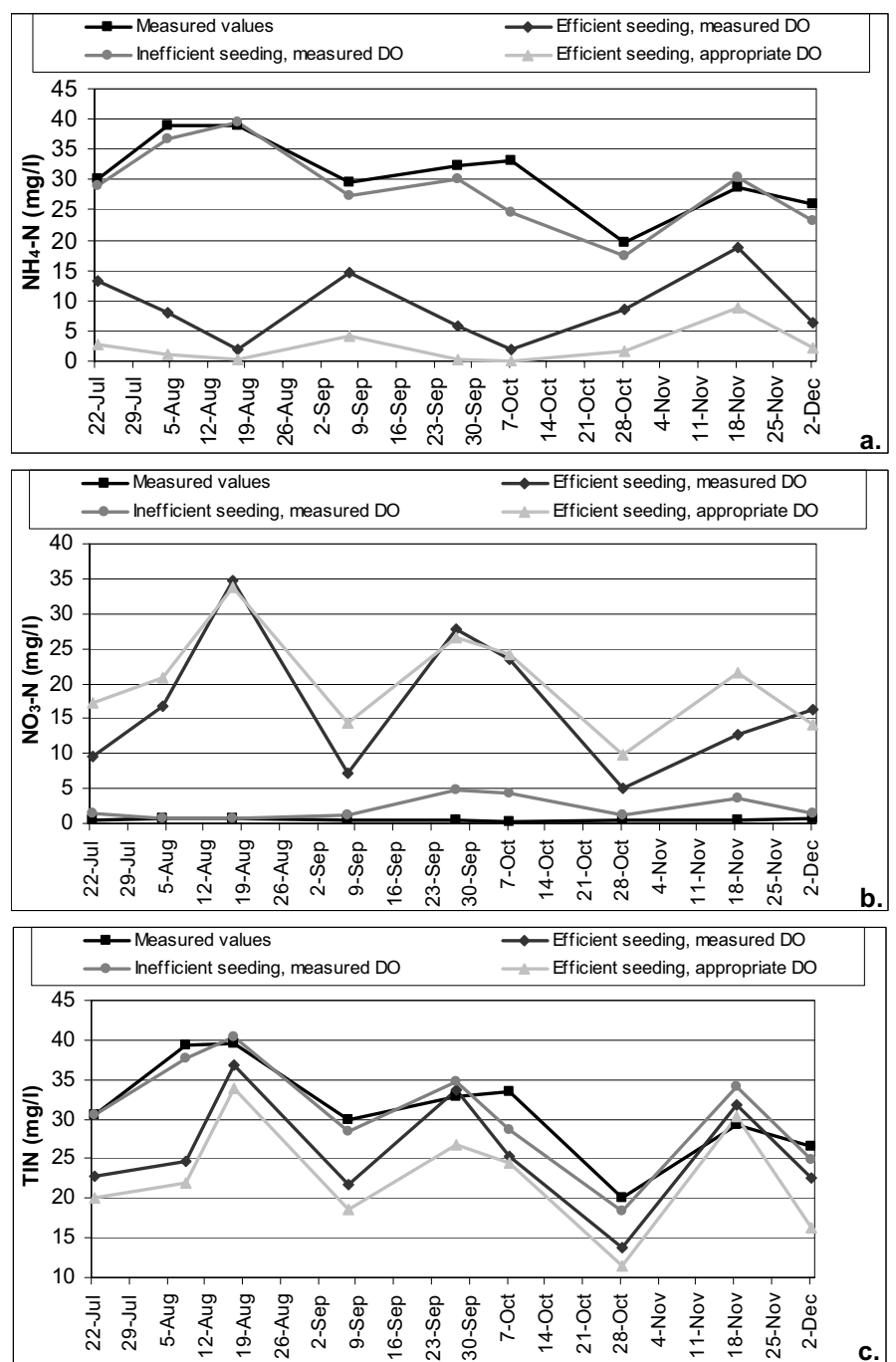

Fig. 4. Calculated and measured activated sludge effluent $\mathrm{NH}_{4}-\mathrm{N}, \mathrm{NO}_{3}-\mathrm{N}$, TIN concentration values

Evaluation of the full-scale results showed that in the investigated period the aeration was not sufficient for covering the oxygen demand of the efficient growth of nitrifiers. Simulation results suggested, that appropriate aeration facilitates efficient backseeding, however, improvement of $\mathrm{N}$-removal in the activated sludge system is influenced by the ratio of readily biodegradable carbon source to ammonia content of the influent wastewater.

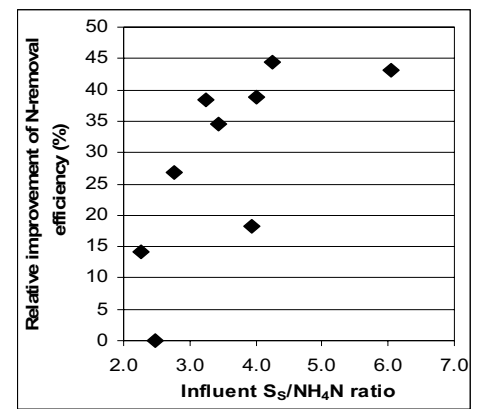

Fig. 5. Relative improvement of N-removal efficiency in the activated sludge system, as a function of influent $\mathrm{S}_{S} / \mathrm{NH}_{4} \mathrm{~N}$ ratio
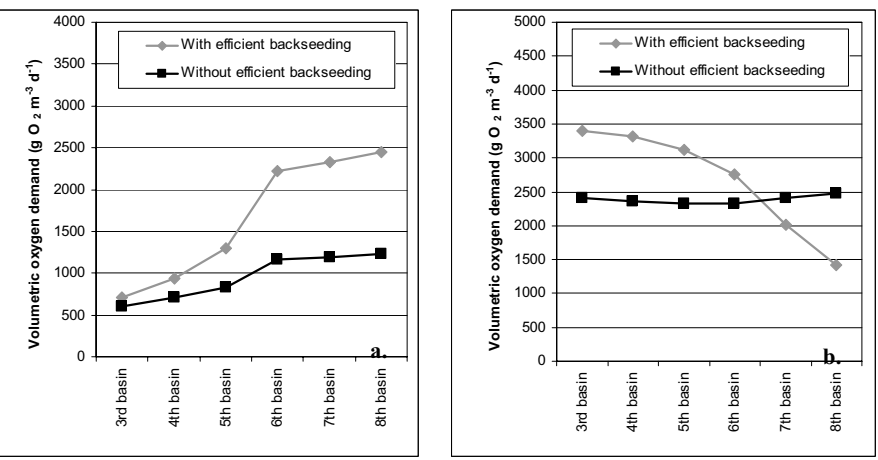

Fig. 6. Calculated volumetric oxygen demand in the activated sludge unit at the measured DO values (a) and appropriate DO values (b).

\section{References}

1 Daigger GT, Norton LE, Watson RS, Crawford D, Sieger RB, Process and Kinetic Analysis of Nitrification in Coupled Trickling Filter/Activated Sludge Process., Water Environment Research 65 (1993), no. 6, 750-758.

2 Daigger GT, Parker DS, Enhancing Nitrification in North American Activated Sludge Plants., Water Science and Technology 41 (2000), no. 9, 97105.

3 Grady CPL, Daigger GT, Lim HC, Biological Wastewater Treatment, Marcel Dekker,Inc., New York, 1999.

4 Jobbágy A, Literáthy B, Farkas F, Garai Gy, Kovács Gy, Evolution of the Southpest Wastewater Treatment Plant, Water Science and Technology 41 (2000), no. 9, 7-14.

5 Jobbágy A, Literáthy B, Tardy G, Enhanced Nitrogen Removal in the Combined Activated Sludge-Biofilter System of the Southpest Wastewater Treatment Plant, Water Science and Technology 50 (2004), no. 7, 1-8.

6 Parker D, Richards JT, Discussion of Process and Kinetic Analysis of Nitrification in Coupled Trickling Filter Activated Sludge Systems., Water Environment Research 66 (1994), no. 7, 934-935. 